\title{
Macromethods For Reducing Aldonic Lactones To Sugars: The Preparation of L-Glucose ${ }^{1}$
}

\author{
Harriet L. Frush and Horace S. Isbell
}

\begin{abstract}
Two macroprocedures are described for the efficient reduction of lactones of aldonic acids by sodium amalgam in the presence of an oxalate buffer. One employs a stainless-steel flask equipped with a stirrer that sweeps the bottom of the flask; the other, a high-speed "blender." Either method is suitable for the preparation of rare sugars in relatively large quantities. By the procedures described, L-glucose has been prepared from L-glucono- $\delta$ lactone in 88-percent yield, for use as carrier in the preparation of $\mathrm{L}$-glucose-1-C ${ }^{14}$.
\end{abstract}

\section{Discussion}

Synthesis of sugars by the cyanohydrin method of Kiliani and Fischer has been, and still remains, of great importance to carbohydrate chemistry. Originally, the process was tedious and the yields were low. Thus, in the classical synthesis of Lglucose from L-arabinose the over-all yield was only 3 percent [1]. ${ }^{2}$ Although the technique of reduction by sodium amalgam has since been improved $[2,3$, $4]$, the procedure has nevertheless been laborious and somewhat variable as to results. For use in the svnthesis of $\mathrm{C}^{14}$-labeled sugars on a semimicroscale, a convenient procedure was recently developed for the sodium-amalgam reduction of millimole quantities of aldonic lactones in vields as high as 85 to 90 percent $[5,6]$. The reduction is carried out in a closed system. Accurate $p \mathrm{H}$ control is obtained by using an excess of a slightly soluble acid salt (sodium acid oxalate) as a buffering agent. This avoids the necessity for continual adjustment of $p \mathrm{H}$ by titration of the alkali formed in the reaction. The method has now been adapted to macropreparations with equally successful results. Two procedures were found to be convenient for the reduction of a 5 - or $10-\mathrm{g}$ quantity of lactone. The simpler and more rapid procedure involves treatment of the lactone with sodium amalgam and excess sodium acid oxalate in a high-speed "blender" partially filled with ice. The maximum yield of sugar from the lactone compares favorably with that obtained in the semimicro apparatus [7], and requires approximately the same proportion of amalgam; the reaction is complete in $15 \mathrm{~min}$. For the preparation of $\mathrm{C}^{14}$ labeled sugars, however, the procedure is complicated by the formation of mist, or spray, that is difficult to confine to the apparatus. The second procedure for reduction makes use of a stainless-steel flask equipped with a stirrer that sweeps the bottom of the flask. The amount of sodium amalgam necessary for maximum yield of the sugar was found to depend somewhat on the efficiency of stirring, and, in the apparatus employed, was 2 or 3 times as large per

Part of a project on the development of methods for the synthesis of radioactive carbohydrates sponsored by the Atomic Energy Commission.

Figures in brackets indicate the literature references at the end of this paper. mole of lactone as that required in the blender. However, the two procedures give comparable results, and both are suitable for the macroreduction of any aldonic lactone. ${ }^{3}$

\section{Experimental Procedures}

\subsection{Reduction of L-Glucono- $\delta$-Lactone to L-Glucose in a High-Speed Blender}

Approximately $500 \mathrm{ml}$ of ice slush was agitated with $55 \mathrm{~g}$ of sodium acid oxalate and $10 \mathrm{~g}$ of L-glucono- $\delta$-lactone in a high-speed blender having stainless-steel blades. After a few seconds, $130 \mathrm{~g}$ of 5-percent sodium amalgam pellets [8] was added quickly; agitation was continued for $15 \mathrm{~min}$, during which time the temperature rose to $33^{\circ} \mathrm{C}$. The mercury was then separated, and the solution was neutralized with dilute sodium hydroxide solution until a faint but permanent pink color was obtained in the presence of phenolphthalein indicator. The solution was evaporated under reduced pressure to a volume of about $100 \mathrm{ml}$ and treated with 5 volumes of methanol. The precipitated salts were separated, washed with a little methanol, and discarded. The filtrate was concentrated under reduced pressure to about $50 \mathrm{ml}$, and again treated with 5 volumes of methanol. Precipitated salts were removed by filtration, and the solution, after concentration under reduced pressure to about $50 \mathrm{ml}$, was deionized by passage through $60 \mathrm{ml}$ of mixed cation and anion exchange resins in a column having a layer of cation exchange resin at the bottom. ${ }^{4}$ The neutral solution. and washings from the column were evaporated under reduced pressure to a thin sirup (about $10 \mathrm{ml}$ ), which was diluted with an equal amount of methanol, and then with 2-propanol almost to the point of turbidity. The solution gave $8.92 \mathrm{~g}$ of crvstalline L-glucose in three crops, corresponding to 88.3 percent of the theoretical yield.

The aldonic lactones vary considerably in ease of reduction and in the tendency of the sugar to be reduced further to the corresponding sugar alcohol. Consequently, the optimum amount of amalgam to be used must be determined for each lactone reduced.

${ }_{4}$ Equivalent quantities of Amberlite $1 \mathrm{R}-120-\mathrm{H}$, analytical grade, Rohm \& Haas Co.. Philadelphia, Pa., and Duolite A-4, Chemical Process Co.. Redwood City, Calif. The layer of cation exchange resin at the bottom of the column gives rise to an acid reaction in the effluent when insufficient mixed resin is used. 
2.2. Reduction of D-Glucono- $\delta$-Lactone-1-C $\mathrm{C}^{14}$ on a Relatively Large Scale in a Stainless-Steel Flask

Eighty grams of sodium acid oxalate, $7 \mathrm{~g}$ of crude D-glucono- $\delta$-lactone-1-C $\mathrm{C}^{14}$ having an activity of 5,330 $\mu \mathrm{c}$, and $500 \mathrm{ml}$ of ice water were placed in a twonecked, 1-liter, stainless-steel flask equipped with an efficient stirrer. ${ }^{5}$ The solution was stirred vigorously and $180 \mathrm{~g}$ of 5 -percent sodium amalgam pellets was added at one time. After $2 \mathrm{hr}$ of stirring at ice-bath temperature, the mercury was separated; the reaction mixture was made alkaline to phenolphthalein and then carefully neutralized with oxalic acid. ${ }^{6}$ The crystalline sodium salts were separated and washed with methanol. The combined aqueous solution and methanol wash liquor were concentrated under reduced pressure to about $250 \mathrm{ml}$, after which a crop of crystalline sodium oxalate was separated by filtration, washed with methanol, and discarded. The filtrate was concentrated to about $20 \mathrm{ml}$ at a temperature less than $40^{\circ} \mathrm{C}$, and another crop of salts was separated. The resulting solution was concentrated under reduced pressure at $30^{\circ} \mathrm{C}$ to a sirup that was then diluted with 5 volumes of methanol. The mixture was filtered, and the residue was washed with $30 \mathrm{ml}$ of methanol in 3 portions. Finally, the methanol solution was diluted with an equal volume of ethanol, and the salts that precipitated were separated by filtration and washed with methanol. The filtrate was concentrated to remove most of the alcohol; the resulting solution was diluted with $50 \mathrm{ml}$ of water and was passed over a column containing 100 $\mathrm{ml}$ of mixed cation and anion exchange resins. The

\footnotetext{
5 The stirrer consisted of a stainless-steel rod fitted with a curved vane, $7 \mathrm{~cm}$ long, that conformed in shape to the flask and swept the bottom.

6 The solution must be kept neutral during the steps that follow to avoid undesirable reactions.
}

column was washed with water, the combined solution ${ }^{7}$ and washings were evaporated to $50 \mathrm{ml}$ under reduced pressure at a temperature less than $40^{\circ} \mathrm{C}$, and the solution was then freeze-dried. The residue was taken up at once in $15 \mathrm{ml}$ of methanol and brought to crystallization by the addition of 2-propanol to the point of incipient turbidity. The crystalline D-glucose-1-C ${ }^{14}$ that formed, after separation and recrystallization, weighed $5.47 \mathrm{~g}$ and contained $3,954 \mu \mathrm{c}$ of carbon-14. By use of nonradioactive carrier, an additional $658 \mu \mathrm{c}$ of crystalline $\alpha$-D-glucose-1-C ${ }^{14}$ was obtained. Thus the radiochemical yield was 4,612 $\mu \mathrm{c}$, or 84.3 percent of the theoretical. ${ }^{8}$ By elution with 10-percent aqueous acetic acid of the mixed resin used for the purification of the sugar, crude Dgluconic acid-1-C ${ }^{14}$ with an activity of $645 \mu \mathrm{c}$ was recovered.

7 The $p \mathrm{H}$ of the solution at this point must be close to 7 ; otherwise, additional resin must be used.

8 In reductions of pure nonradioactive D-glucono- $\delta$-lactone, yields of approximately 90 percent were obtained.

\section{References}

1] E. Fischer, Ber. deut, chem. Ges. 23, 2618 (1890).

[2] M. Steiger, Helv. Chim. Acta 19, 180 (1936).

[3] F. J. Bates and associates, Polarimetry, saccharimetry and the sugars, NBS Circular 440, p. 465 (1942)

[4] N. Sperber, H. E. Zaugg, and W. M. Sandstrom, J. Am. Chem. Soc. 69, 915 (1947).

[5] H. S. Isbell, U. S. Patent 2,632,005 (1953).

[6] H. S. Isbell, J. V. Karabinos, H. L. Frush, N. B. Holt, A. Schwebel, and T. T. Galkowski, J. Research NBS 48, 163 (1952) RP2301.

[7] H. L. Frush and H. S. Isbell, J. Research NBS 50, 133 (1953) RP2400.

[8] H. L. Frush and H. S. Isbell, J. Research NBS 51, 307 (1953) RP2458.

WAshington, January 21, 1955. 